\title{
Handledarens frågor: Att möjliggöra självständighet i ett handledningssamtal
}

\author{
Jenny Magnusson \\ Södertörns högskola
}

\begin{abstract}
Ett av många ansvarsområden som en uppsatshandledare har handlar om att möjliggöra och öppna för studentens självständighet. Självständighet knyts i den här undersökningen till studentens delaktighet i handledningssamtalen, och i det sammanhanget är handledarens frågor till studenten centrala. Syftet är därför att undersöka hur handledarna genom ställandet av frågor öppnar för och möjliggör studentens självständighet. Åtta olika handledarsamtal från två utbildningsprogram analyseras utifrån vilka frågor som ställs, och vilka av dessa frågor som öppnar för och möjliggör självständighet. Tre typer av frågor identifieras som särskilt centrala i handledningssamtalen; öppnande och överlämnande frågor, utvecklande och fördjupande frågor samt utmanande och problematiserande frågor. Variationen mellan samtal och handledare visar sig dock vara stor och det visar sig också finnas skillnader i vilken typ av delaktighet som skapas med hjälp av frågorna.
\end{abstract}

Nyckelord: handledning, frågor, uppsats, handledningssamtal, delaktighet, självständighet

\section{INLEDNING}

Att handleda studenters självständiga arbeten inom högre utbildning innebär en mängd olika saker. En handledare förväntas i sin roll vara allt från lärare och expert till samarbetspartner och medmänniska. En handledare ska både stödja, styra och kontrollera, men också möjliggöra och öppna för studentens självständighet. Det finns en motsättning i de olika förväntningar och krav som ställs på en handledare, och det är inte helt enkelt att som handledare uppfylla alla dessa förväntningar i praktiken (jfr Forsberg \& Lundgren, 2006; Lendahls Rosendahl, I998; Dysthe, 2002; Ekholm, 20I2). Det handlar grovt sett om två ytterligheter, studentens självständighet som ställs emot handledarstyrning.

Just självständighet är ett centralt begrepp inom den högre utbildningen, inte minst i samband med uppsatsskrivande (jfr Magnusson \& Zackariasson, 2oI8). Självständighet som begrepp kan dock förstås på många olika sätt, till exempel som att studenten ska ta initiativ och styra sitt eget lärande, förhålla sig till källor av olika slag, göra val, ta ansvar och argumentera för sin sak (Magnusson \& Zackariasson, 20I8).

Mycket av det som har med självständighet att göra kan knytas just till handledningen. I handledningen kan studenten ta initiativ, visa ansvarstagande, göra val och argumentera för sin sak. Detta innebär att handledaren fungerar som den som ska uppmuntra och möjliggöra denna form av självständighet, men också i vissa fall vara den som ska rapportera om detta till examinatorn i de fall detta också finns med i lärandemål och betygskriterier.

*Författarkontakt: jenny.magnusson@sh.se

Artiklar och reflektioner är kollegialt granskade. Övriga bidragstyper granskas av redaktionen. Se https://hogreutbildning.se ISSN 2000-7558

(C)2021 Jenny Magnusson. This is an Open Access article distributed under the terms of the Creative Commons Attribution-NonCommercial 4.0 International License (https://creativecommons.org/licenses/by-nc/4.0/), allowing third parties to share their work (copy, distribute, transmit) and to adapt it, under the condition that the authors are given credit, that the work is not used for commercial purposes, and that in the event of reuse or distribution, the terms of this license are made clear.

Citation: Magnusson, J. (2021). "Handledarens frågor: Att möjliggöra självständighet i ett handledningssamtal», Högre utbildning, 11(1), 56-75. https://doi.org/10.23865/hu.v11.2296 
Det går att utifrån ovannämnda perspektiv beskriva självständighet som en form av delaktighet i handledning. Det handlar då om att studenten yttrar sig och deltar i handledningsinteraktionen $\mathrm{i}$ form av frågor och svar, resonemang och tankegångar, men också att studenten tar initiativ till interaktion och samtalsämnen och därmed styr sitt eget lärande. Det är denna form av självständighet i form av delaktighet som står i centrum för denna artikel, och delaktigheten kan variera och vara mer eller mindre omfattande, mer eller mindre ett uttryck för självständighet. Hur kan handledaren då göra för att öppna för och uppmuntra till självständighet i handledningen?

Handledning kan sägas bestå av två olika huvudsakliga typer av aktiviteter, handledarens återkoppling på i förväg lästa textutkast och studentens rapportering av och beskrivning av arbetsprocessen (jfr Vehviläinen, 20I2). Handledarens centrala verktyg i dessa aktiviteter är att ge råd och ställa frågor till studenten. Framförallt frågorna är verktyg som handledare kan använda sig av för att uppmuntra till självständighet hos studenten. Frågor kan uppmuntra till aktivitet, handling och delaktighet, och styr också vilken typ av aktivitet, handling och delaktighet som förväntas av studenten.

Handledningssamtal är asymmetriska till sin natur givet studentens och handledarens olika institutionella roller (jfr Linell, 20II). Den som ställer mycket frågor i ett institutionellt samtal är ofta också den som styr och ansvarar för interaktionen som helhet (jfr Freed \& Ehrlich, 20Io), vilket innebär att frågorna också avgör vilken handledarroll som handledaren intar. Frågor kan användas för att uppmuntra debatt och stimulera till diskussion, men de kan också användas för att tysta eventuell opposition och argumentation (jfr Holmes \& Chiles, 20I0, s. I87), något som Bubel (2005, s. 243) beskriver som att "in certain contexts, questions engineer authority and dominance rather than equality and solidarity". Den här potentiella spänningen när det gäller användningen av frågor i handledning är en utgångspunkt i denna undersökning, liksom den spänning som finns mellan att som student vara självständig och att handledas.

Utifrån ovanstående resonemang är syftet i denna artikel att undersöka om och i så fall hur handledares frågor i handledarsamtal möjliggör och främjar självständighet hos studenten.

- Vilka frågor använder handledarna som öppnar för och möjliggör självständighet och vilken självständighet leder dessa till hos studenterna?

- Hur ser variationen ut mellan vilka typer av frågor olika handledare ställer och mellan var i handledningsprocessen frågorna ställs?

\section{TIDIGARE FORSKNING}

Frågor har analyserats under många år och utifrån olika vetenskapliga perspektiv, till exempel kognitiva/psykologiska, språkvetenskapliga och pedagogiska. Språkliga analyser av frågor har gjorts på olika nivåer - syntaktisk, prosodisk, pragmatisk etc. (jfr Freed, 1994). Hur frågor används och vad frågor har för funktion har också studerats, och det har då framkommit att frågor kan användas på många olika sätt och få olika typer av funktioner i samtal. Just hur frågor används och vilken funktion de har i handledningsinteraktion har dock inte studerats specifikt.

Freed har kategoriserat frågors funktion i en studie av informella samtal, en kategorisering som har fungerat som utgångspunkt i flera andra studier. Kategoriseringen bygger på typ av information som frågorna ger uttryck för eller efterfrågar i sina bestämda kontexter, och såväl tydliga mönster som tydliga variationer har identifierats. Variationerna rör sig mellan rena faktafrågor till frågor som ger uttryck för känslor, och Freed konstaterar att det finns många frågor som inte efterfrågar information överhuvudtaget. Holmes och Chiles (20I0) har använt Freeds 
funktionella kategorisering för att analysera frågor som verktyg för kontroll i arbetsplatskommunikation, och har anpassat Freeds kategorisering till detta. Även i föreliggande studie är just frågors funktion central, men tematiseringen kommer här att göras utifrån vad som visar sig vara relevant just i en akademisk handledningskontext, och vad som är relevant utifrån ett självständighetsperspektiv.

Frågor har också analyserats i olika institutionella kontexter utifrån ett samtalsanalytiskt eller pragmatiskt perspektiv. Förutom Holmes och Chiles (2010) analyser av arbetsplatskommunikation har klassrum analyserats (Heath, 1982), konferenser (Holmes, 1992), domstolar (Philips, 1984), läkarsamtal (Ainsworth-Vaughn, 1998) och nyhetsmedier (Piirainen-Marsh, 2005). Föreliggande studie bidrar med kunskaper om frågor i just en akademisk institutionell kontext genom analys av interaktionella mönster.

Analyserna av frågor i institutionella kontexter har handlat om sådant som makt och relationen mellan form och funktion. När det gäller makt är det vanligast att negativa, kritiserande och begränsande frågor har analyserats och att frågors auktoritativa kontrollerande funktion fokuserats (Heritage, 2002; Holmes \& Chiles, 20IO; Yieke, 2002). I denna studie om handledares frågor är det närmast motsatsen som fokuseras, hur frågorna öppnar upp för självständighet i form av deltagande; samspel och studentautonomi.

Även olika former av frågor har analyserats i olika studier: ja- och nej-frågor (Heinemann, 2008), retoriska frågor (Frank, I990; Rohde, 2006), flerledade frågor (Hofvendahl, 2000; Linell, Hofvendahl \& Lindholm, 2003) och negativt formulerade frågor (Heritage, 2002). I föreliggande studie analyseras olika former av frågor som öppnar för och möjliggör självständighet, men formen är inte det centrala. Makt och auktoritativ funktion är dock centralt, men utifrån ett närmast motsatt perspektiv där frågorna som undersöks möjliggör minskande av makt och auktoritet.

I en pedagogisk kontext har klassrumsfrågor undersökts, och då framförallt skillnaden mellan frågor som efterfrågar ny information och frågor som kontrollerar information (t.ex. Banbrook \& Sjehan, 1990). Det är mer ovanligt med studier av frågor i andra pedagogiska kontexter. I en studie från en pedagogisk kontext liknande högskolans undersöks dock frågor som ställs av collegestudenter och handledare i handledningssamtal där fokus ligger på frågors kvalitet, vilket knyts till hur frågor i större eller mindre utsträckning efterfrågar djupa och komplexa resonemang (Graesser \& Person, 1994). I en ytterligare studie från en akademisk handledningskontext undersöks innehållsliga teman i lärarstudenters frågor i skriftlig återkoppling (Gustavsson \& Eriksson, 2015). Det framgår där att studenterna genom sina frågor styr handledaren mot en auktoritativ expertroll. Det är alltså inte enbart handledarens eller pedagogens frågor som spelar roll för hur asymmetrisk handledningsinteraktionen blir. Skillnaderna mellan frågor som ställs i olika pedagogiska kontexter undersöks därutöver i Koshiks (20I0) studie. Koshik identifierar olika typer av frågor där frågeställaren redan vet svaret. Koshiks studie, som undersöker frågor mellan lärare och utbytesstudenter i skrivarverkstäder, visar att det förekommer olika typer av frågor och funktioner i de olika pedagogiska kontexterna, och visar därmed på behovet att studera olika typer av pedagogiska kontexter för att se hur dessa skiljer sig och hur pedagogik "görs" annorlunda i dessa kontexter. Handledning inom högre utbildning är en sådan annan pedagogisk kontext, där man kan förvänta sig att frågemönster och funktioner skiljer sig.

Det finns därutöver forskning om självständighet i en högskolekontext som är relevant i relation till utgångspunkterna för denna studie. Självständighet undersöks utifrån ett handlednings- och interaktionsperspektiv inom ramen för det forskningsprojekt som denna studie är en del av (Magnusson, 20I5, 20I6, 2020a, 2020b; Magnusson \& Sveen, 20I3, 20I4; Magnusson 
\& Zackariasson, 20I8; Sveen \& Magnusson, 2013; Zackariasson, 2019), där det framgår att det finns många olika sätt att förstå självständighet på och att självständighet är relevant att studera just i handledningsinteraktion.

Föreliggande studie bidrar till mer kunskap om frågors användning i specifika pedagogiska kontexter i allmänhet och den institutionella handledarkontexten i högre utbildning i Sverige i synnerhet. Fokus i undersökningen ligger på frågors funktion snarare än innehållsliga teman, och behandlar en särskild sorts frågor som inte har fokuserats specifikt tidigare - frågor som öppnar för självständighet.

\section{MATERIAL OCH METOD}

Undersökningen utgår till viss del från en samtalsanalytisk ram, i och med att autentiska samtal fungerar som utgångspunkt för analysen och genom att samspelet i interaktionen får betydelse (Linell, 20II). Den huvudsakliga ansatsen är dock pragmatisk funktionell genom att frågors funktioner analyseras både innehållsligt och sekventiellt utifrån frågeepisodens kontext.

Materialet består av samtliga frågor som förekommer i åtta olika handledningssamtal från lärarutbildning och journalistikutbildning, med fyra olika handledare, två kvinnor (K) och två män (M). Detta material är en del av ett större material som samlats in inom ramen för ett forskningsprojekt som rör självständighet inom högre utbildning. Inom ramen för detta projekt har två kvinnor och två män valts ut slumpmässigt. Det är en eller två studenter som handleds av respektive handledare, en skillnad som skulle kunna ha betydelse för asymmetri och balans i samtalen och därför är markerad. Det första och sista handledningssamtalet med respektive handledare och student/par har valts ut som material. Att just första och sista samtalen är utvalda är för att det alltid finns minst två samtal och därför alltid finns just ett första och sista samtal, men också för att få en bredd i samtal från olika delar av processen. Samtalen är mellan 27 och 50 min, och har spelats in med ljud. I materialöversikten nedan (tabell I) framgår:

- antal handledare och vilket kön, kvinna eller man $(\mathrm{K} / \mathrm{M})$, respektive handledare har (kolumn I, Nr, I-4)

- antal studenter som handleds och vilket kön, kvinna eller man (K/M), dessa har (kolumn 2, St)

- samtalens längd och huruvida det är det första (I) eller sista (2) samtalet som handledaren håller i (kolumn 3, Samtal)

- datum för inspelning (kolumn 4, Dat)

- antal frågor som handledaren ställer i samtalet ifråga (kolumn 5, Frågor)

- genomsnittligt antal frågor per minut som handledaren ställer (kolumn 6, Frågor/min).

Frågor

De inspelade samtalen har transkriberats och 207 frågor har identifierats och analyserats i materialet.

Det finns ingen entydig definition av vad en fråga är. Det finns alltså inte ett särskilt lingvistiskt kriterium som räcker för att avgöra vad som är en fråga eller om ett yttrande eller en fras ska förstås som frågande (jfr Freed \& Ehrlich, 20Io, s. 6). Frågor kan lite förenklat definieras syntaktiskt, prosodiskt, eller utifrån hur de funktionellt uppfattas i interaktionen (Hofvendahl, 2000).

1 Forskningsprojektet heter "Independence in higher education. A comparative study of Sweden and Russia” (2016-2020) och är finansierat av Östersjöstiftelsen, 2015/3.1.1/1423. 
Tabell I. Materialöversikt

\begin{tabular}{|c|c|c|c|c|c|}
\hline $\mathrm{Nr}$ & St & Samtal & Dat & Frågor & Frågor/min \\
\hline I $(\mathrm{M})$ & $(\mathrm{K}, \mathrm{K})$ & Samtal I (oo:32:56) & I605II & 28 & 0,8 \\
\hline I $(M)$ & $(\mathrm{K}, \mathrm{K})$ & Samtal 2 (00:41:05) & 160313 & 23 & 0,6 \\
\hline $2(\mathrm{M})$ & $(\mathrm{K})$ & Samtal I (oo:49:50) & 171024 & 29 & 0,6 \\
\hline $2(\mathrm{M})$ & $(\mathrm{K})$ & Samtal 2 (oo:27:3I) & I7IIIII & I4 & 0,6 \\
\hline $3(\mathrm{~K})$ & $(\mathrm{K})$ & Samtal I (oo:47:48) & III216 & 39 & 0,8 \\
\hline $3(\mathrm{~K})$ & $(\mathrm{K})$ & Samtal 2 (oo:37:43) & $\mathrm{I} 2 \mathrm{OIO} 3$ & 42 & $\mathrm{I}, \mathrm{I}$ \\
\hline $4(\mathrm{~K})$ & $(\mathrm{K}, \mathrm{K})$ & Samtal I (oo:23:15) & I6040I & I8 & 0,8 \\
\hline $4(\mathrm{~K})$ & $(\mathrm{K}, \mathrm{K})$ & Samtal 2 (oo:35:59) & 160520 & I4 & 0,4 \\
\hline
\end{tabular}

I sin mest grundläggande form är en fråga en typ av social handling med en särskild syntaktisk utformning, en frågestruktur eller en interrogativ syntax, som används för att efterfråga information i en interaktionssituation. En frågestruktur är en sorts förening av grammatik och social handling och innebär att vanliga frågor som "Vad handlar boken om?" och "Hur hittar man till busshållplatsen?" är uppbyggda på samma sätt och har som syfte att efterfråga information. Det finns dock många andra möjliga sätt att fråga på, och alla frågor har inte heller som syfte att efterfråga information. Yttranden eller fraser som prosodiskt definieras som frågor avslutas med en så kallad frågeton eller frågeprosodi, en höjd ton (jfr Linell, 20II, s. 320).

Ett tredje sätt att definiera en fråga på har med funktionen att göra, hur frasen uppfattas av en mottagare i samtalsinteraktionen. Uppfattar mottagaren det som sägs som en fråga är det också en fråga utifrån detta perspektiv. Att en deltagare uppfattar någonting som en fråga framgår i responsen på frågan som ställs, vilket i praktiken innebär att om studenten svarar på yttrandet som görs med frågesyntax eller frågeprosodi ses det som en fråga.

I den här artikeln har frågor definierats både prosodiskt, syntaktiskt och funktionellt. En fråga förstås här som det som syntaktiskt och/eller prosodiskt fungerar som frågor, och som också uppfattas som frågor av deltagarna i interaktionskontexten (Sinclair \& Coulthard, 1992, s. 19). Detta innebär alltså att en fråga i den här studien är en fras eller ett yttrande som har en syntaktisk interrogativ frågestruktur eller en avslutande frågeintonation, och som samtidigt funktionellt uppfattas som en fråga av mottagaren genom att svar på frågan ges.

Påståendeyttranden och andra former av yttranden med en frågeton eller frågeprosodi som förstås som frågor av deltagarna i interaktionen ses här alltså som frågor, liksom påståendeyttranden som avslutas med tag questions, "eller hur?", och som uppfattas som frågor i interaktionen. Yttranden som syntaktiskt utformas som frågor men som inte uppfattas som frågor $\mathrm{i}$ kontexten ingår enligt samma princip alltså inte i materialet, till exempel retoriska frågor.

Frågor brukar diskuteras som delar av ett närhetspar (adjacency pairs), sekvenser som består av fråga och svar i en enhet (jfr Schegloff, Jefferson \& Sacks, 1974). I analysen av frågor har svaren därför också tagits med som en del av den relevanta kontexten. Det är i första hand episoden där en fråga använts som fungerar som relevant kontext och analysenhet. Episoder ses här som interaktionellt och topikalt sammanhängande sekvenser (jfr Linell, 20II, s. 345). Ibland är det en lång frågeepisod med flera stegvisa frågor som analyseras, eller också är det analyserade meningsutbytet kort, enbart inkluderande ett närhetspar, en fråga och ett svar.

För att kunna analysera hur frågor används är funktionen särskilt central. Funktion definieras här som den sociala handling som utförs genom att en fråga används i interaktionen, eller 
som den interaktionella, pragmatiska eller sociala användning som frågor får i interaktionen (jfr Freed, 1994, s. 642). Frågornas funktion har analyserats med utgångspunkt i tolkningar av fråge-episodens utformning och kontext. Det som har tagits fasta på är vad för typ av information som efterfrågas i frågan, var i ett samtal eller en episod frågan kommer, om frågan följs av följdfrågor etc. Här kommer analysen alltså att ha en mer pragmatisk funktionell utgångspunkt, och inte i första hand en samtalsanalytisk.

I denna studie har materialet analyserats induktivt och samtliga frågor i de åtta samtalen har inledningsvis identifierats. Som i alla induktiva kategoriseringar finns tveksamma fall, frågor som skulle ha kunnat kategoriseras utifrån fler funktioner. Detta kommer att beröras i analysen där det är relevant. I ett andra steg har frågor, som utifrån analysen har som funktion att öppna för och möjliggöra studentens självständighet, analyserats mer specifikt, och här har också frågan som del av ett närhetspar och del av en frågeepisod analyserats särskilt, där studentens respons på handledarens fråga inkluderas i analysen.

Dessa frågor analyseras utifrån tre olika aspekter:

I) Vilka eventuella likheter och skillnader som förekommer i relation till frågor med en viss funktion

2) Hur frågorna öppnar för deltagande

3) Vilken respons frågorna får av studenten

Den aspekt av självständighet som undersöks i denna studie kan definieras som delaktighet. Delaktighet kan innebära många saker, men här avses studentens aktivitet och delaktighet i undervisning/handledning (jfr Skolverket, 20I5). På en övergripande nivå handlar det om studentens talutrymme, möjlighet att bidra och uttrycka sig. På en annan nivå handlar det om initiativtagande och inflytande över vad som diskuteras, möjligheten att fatta beslut och göra val (jfr Magnusson \& Zackariasson, 2018). Det som avses kan beskrivas som en närmast politisk delaktighet (jfr Koster, Han Nakken \& Van Houten, 2009), där beslutsfattande och inflytande är det centrala, snarare än en social delaktighet där relationer och tillhörighet är det centrala. Denna typ av politisk delaktighet i beslutsfattande och inflytande är viktig för studenters engagemang och lärande inom den högre utbildningen, men är också avgörande för utbildningskvalitet generellt (jfr Bergmark \& Westman, 20I6; Studentkårer, 20I3). Särskilt fokus riktas alltså mot hur handledaren genom frågor möjliggör för studenten att delta, ta initiativ, fatta beslut och ha ett inflytande över sitt lärande i olika avseenden, till exempel när det gäller val av topik (ämne), beskrivningar av planer och idéer etc. Det handlar om att genom frågor möjliggöra aktörsskap och se till att studenten är en aktiv och samskapande part i samtalet och samspelet, vilket kan knytas till en sociokulturell syn på lärande som skapas i socialt samspel mellan individer (jfr Säljö, 2000). Detta kan också knytas till det som Dysthe (2002) kallar för partnerskapsmodellen (the partnership model), som innebär att handledare och student har en symmetrisk relation som bygger på dialog och inte på att handledaren i en asymmetrisk dialog styr och tar över arbete och diskussioner.

\section{RESULTAT}

I resultatet framgår det att det finns såväl tydliga likheter som tydliga skillnader i vilka frågor som handledarna ställer. Frågorna är på en övergripande nivå relativt likartade och fyller likartade funktioner. Det är framförallt tre vanliga frågefunktioner i materialet som kan sägas möjliggöra studentens delaktighet och därmed självständighet i handledningen - frågor som 
syftar till att öppna för studentens delaktighet i handledningssamtalet, frågor som syftar till att studenten ska utveckla och fördjupa sina resonemang och därmed sin delaktighet och frågor som syftar till att utmana och problematisera det som studenten sagt eller skrivit för att fördjupa delaktigheten. Resultatet presenteras och analyseras utifrån dessa tre funktioner, som benämns öppnande och överlämnande frågor, utvecklande och fördjupande frågor samt utmanande och problematiserande frågor.

Tabell 2. Frägefunktioner (Handledare $\mathrm{I}_{4} 4$ anges med $\mathrm{H}_{\mathrm{I}}-\mathrm{H}_{4}$, samtal $\mathrm{I}$ eller 2 anges $\mathrm{I}_{-2}$ )

\begin{tabular}{lccccccccc}
\hline & HI-I & HI-2 & H2-I & $\mathbf{H}_{2-2}$ & $\mathbf{H}_{3}-\mathbf{I}$ & $\mathbf{H}_{3}-\mathbf{2}$ & $\mathbf{H}_{4-\mathbf{I}}$ & $\mathbf{H}_{4-2}$ & Totalt \\
\hline Totalt antal & $\mathbf{2 8}$ & $\mathbf{2 3}$ & $\mathbf{1 8}$ & $\mathbf{I 4}$ & $\mathbf{2 9}$ & $\mathbf{I 4}$ & $\mathbf{3 9}$ & $\mathbf{4 I}$ & $\mathbf{2 0 6}$ \\
\hline Öppnande och överlämnande frågor & 4 & $\mathrm{I}$ & 2 & 4 & 3 & 2 & $\mathrm{II}$ & $\mathrm{I}$ & 28 \\
Utvecklande och fördjupande frågor & 6 & 4 & 2 & 3 & 4 & 5 & 9 & 2 & 35 \\
Utmanande och problematiserande frågor & 8 & $\mathrm{I} 2$ & 6 & 6 & $\mathrm{I} 8$ & 2 & 7 & 25 & 84 \\
\hline
\end{tabular}

Totalt sett använder handledarna ungefär lika många frågor per minut i handledningssamtalen (se tabell I). Av dessa är problematiserande och utmanande frågor vanligast och öppnande och överlämnande frågor minst vanliga av dessa tre.

Fördelningen av olika typer av frågor skiljer sig dock något mellan de olika handledarna och mellan de olika samtalen (se tabell 2). $\mathrm{H}_{4}$ använder flest öppnande och överlämnande frågor i sitt första samtal och är den enda av handledarna som använder fler öppnande och överlämnande frågor än problematiserande och utmanande frågor i något samtal. Öppnande och överlämnande frågor i ett första handledningssamtal kan tyda på att just topikens utformning diskuteras och också att det är många val som studenten behöver göra inledningsvis i processen, samtidigt som studenten inte formulerat så mycket av tankarna och idéerna i text. I det andra samtalet med samma handledare är det tvärtom knappt någon enda fråga som öppnar för eller överlämnar något studentperspektiv. För både $\mathrm{H}_{4}$ och $\mathrm{H}_{\mathrm{I}}$ ökar antalet problematiserande och utmanande frågor i det sista samtalet, men för $\mathrm{H}_{3}$ är minskningen av problematiserande och utmanande frågor mellan första och andra samtalet stor. Problematiserande frågor i slutet av processen verkar framförallt handla om textnära specifika frågor om sådant som behöver förtydligas och problematiseras. Sådant är det inte relevant att ta upp tidigt i processen när själva uppsatsramen och undersökningens genomförande mer står i centrum. Hi och $\mathrm{H}_{4}$ handleder studenter i par, men det är svårt att se några tydliga mönster som kan knytas just till detta, mer än att det är relativt många frågor i något längre samtal. Trots att det alltså finns tydliga likheter i vilka frågor som är vanliga hos dessa handledare finns också variationer; antal frågor som ställs, var i processen frågorna ställs - och självklart vilka behov just de specifika studenterna har, vilket ämne de skriver inom osv.

Ett exempel på hur variationen även har med det kvalitativa innehållet att göra rör problematiserande och utmanande frågor. För $\mathrm{H}_{3}$ förekommer I8 problematiserande och utmanande frågor i första samtalet, och dessa handlar framförallt om utgångspunkterna för studenternas valda studie. Handledaren frågar vad studenterna menar med olika begrepp, varför de har valt som de har valt etc. I det sista samtalet med samma studentpar förekommer endast två problematiserande och utmanande frågor, och man kan förmoda att studenterna då har kommit längre i sina val och sina motiveringar av utgångspunkter och begrepp. $\mathrm{H}_{4}$ har ett motsatt mönster med 7 problematiserande och utmanande frågor i första samtalet, men 25 problematiserande och utmanande frågor i det sista samtalet. I det sista samtalet är det en i närmast färdig 
text som närläses, och handledaren ställer då problematiserande och utmanande frågor runt formaliaval, särskilda formuleringar etc. Problematiserande och utmanande frågor som används i första samtalet har alltså en annan karaktär och ett annat fokus än motsvarande frågor som används i senare samtal. Här är det alltså en variation mellan frågefrekvens, typ av frågor, samtal och handledare.

\section{Öppnande och överlämnande frägor}

Öppnande och överlämnande frågor öppnar för studenternas delaktighet och därmed självständighet genom att studenterna ges möjlighet att själva styra vad samtalet ska handla om. Dessa frågor fungerar i materialet som initiativ från handledaren, kommer oftast tidigt i samtalen och rör oftast studentens arbetsprocess. I detta material används öppnande och överlämnande frågor av alla handledare, men det är den minst vanliga formen av de tre frågefunktioner som här tas upp.

Frågor som syftar till att öppna för studentens egna perspektiv och beskrivningar inleder alltså nya topiker i handledningssamtalen, topiker som alltså studenterna då får möjlighet att initiera och styra i olika utsträckning. Frågorna kan alltså vara mer eller mindre öppna för studentinitiativ. Vissa frågor öppnar för att studenterna styr både topik och fokus, medan andra kan vara mer handledarstyrda, där studenterna kan välja fokus och perspektiv, men inte topik. Utifrån detta går det att urskilja tre olika typer av öppnande och överlämnande frågor:

I) Frågor som fungerar som hälsningsfraser och som på ett allmänt plan överlämnar möjligheten att styra och ta över samtalet till studenterna:

"Läget?" ( $\left.\mathrm{H}_{4} \mathrm{~S}_{2}\right)$, "Hur känns det?" ( $\left.\mathrm{HI}_{\mathrm{I}} \mathrm{S}_{2}\right)$

2) Frågor som syftar till att studenten ska initiera helt egna topiker:

"Vad undrar ni mest?" ( $\mathrm{H}_{4}, \mathrm{~S}$ ) , "Berätta, vad har hänt sen sist?" ( $\left.\mathrm{H}_{2} \mathrm{~S}_{2}\right)$, "men jag tänkte vi kan i alla fall börja med att ni berättar själva, ja?” ( $\left.\mathrm{H}_{2}, \mathrm{~S}_{\mathrm{I}}\right)$, ”Är det nånting speciellt som du hade tänkt på att du skulle vilja ta upp med mig som du skulle vilja prata med mig om?" $\left(\mathrm{H}_{4}, \mathrm{SI}\right)$

3) Frågor som syftar till att studenten ska ha möjlighet att styra själv vad som ska tas upp, men i relation till en specifik topik:

"Är det någonting som du har tänkt på när det gäller syfte och frågeställningar?” $\left(\mathrm{H}_{3}, \mathrm{~S}_{\mathrm{I}}\right)$, "Vad känner du om metodavsnittet?" ( $\mathrm{H}_{3}$, SI) och "Var det någon speciell kommentar som du fick på seminariet som du inte hade tänkt på förut?" $\left(\mathrm{H}_{3}, \mathrm{~S}_{\mathrm{I}}\right)$

Frågornas funktion är alltså att efterfråga studentens initiativ, men det är inte alltid som frågorna leder till mer utförliga och utvecklade studentresponser. I exempel I krävs fler frågor för att studenten ska ge en mer utvecklad respons och komma med en egen topik att diskutera.

\section{Exempel I}

or $\mathrm{H}$ : jamen berätta vad har hänt sen sist du har ju fått ditt material?

O2 $\mathrm{S}$ : ja

o3 $\mathrm{H}$ : du har börjat bearbeta det?

o4 S: ja

05 H: eh men du har inte börjat skriva så mycket än?

o6 S: nej för jag vet inte om jag är på rätt spår (skratt) jamen om det

07 liksom, jag fastnar på det där tematiska på, tidigare forskning $\left(\mathrm{H}_{2}, \mathrm{~S}_{2}\right)$ 


\section{Jenny Magnusson}

Frågeepisoden inleds med att handledaren ställer en öppen och överlämnande fråga där studentens initiativ och val av topik efterfrågas, "Vad har hänt sen sist?", men också en mer preciserande öppen fråga som relevantgör en särskild topik eller omständighet, att studenten har fått sitt material ( $\mathrm{rad}$ I). Studenten svarar kortfattat, "ja" ( $\operatorname{rad} 2)$, vilket här förstås som ett svar på den mer preciserande frågan om studentens material. När studenten inte utvecklar sitt svar ställer handledaren en till utvecklande fråga som har med materialet att göra ( $\operatorname{rad} 3)$, men studenten svarar kort "ja" ( $\operatorname{rad} 4)$ utan att utveckla någon särskild topik även utifrån denna fråga. Det är först efter handledarens tredje fråga, "men du har inte börjat skriva så mycket än?" (rad 6-7) som studenten utvecklar ett förslag på en annan topik som studenten menar sig ha fastnat på, tidigare forskning $(\operatorname{rad~6-7)}$. Den tredje frågan är dock inte öppen och överlämnande utan istället utmanande och problematiserande.

I detta exempel krävs alltså tre eller egentligen fyra frågor för att studenten ska bli delaktig och ta initiativ och utveckla egna tankegångar runt en topik eller ett perspektiv som studenten väljer själv. Det är här inte den öppna och överlämnande frågan som studenten ger en utvecklad respons på utan den problematiserande och utmanande frågan, vilket gör att samtalet och topiken genom detta blir mer problemorienterat, där studenten både försvarar sig mot den utmanande och problematiserande frågan som rör att studenten ännu inte har kommit igång med sitt skrivande samtidigt som att en ny topik introduceras, tidigare forskning ( $\mathrm{rad} 7$ ). Topiken tidigare forskning diskuteras sedan vidare, utifrån studentens initiativ.

I exempel 2 inleder handledaren det första handledarsamtalet med en öppen och överlämnande fråga, "Vad undrar ni mest?"

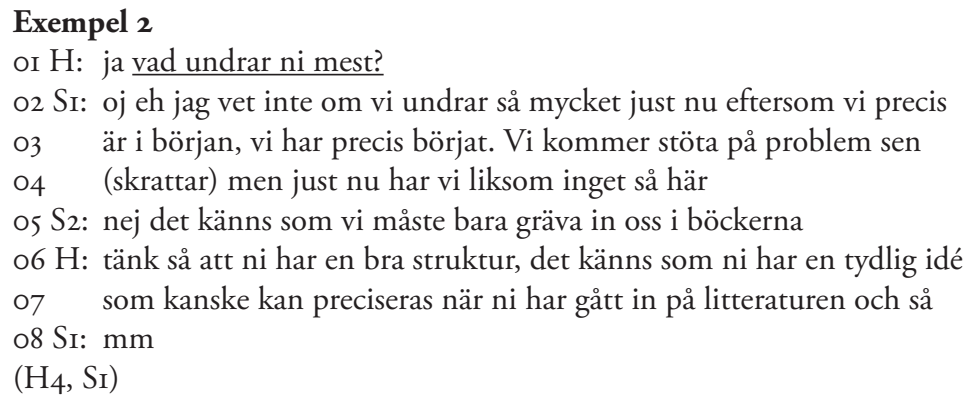

Studenterna svarar avböjande på frågan och avstår därmed möjligheten till delaktighet, och menar att de inte undrar något eftersom de precis har börjat sin skrivprocess ( $\operatorname{rad} 2-4)$. Då initierar istället handledaren en topik genom att rekommendera dem att precisera sin uppsatsidé när de "har gått in på litteraturen". Här får alltså studenterna ytterligare en chans till delaktighet genom att ta initiativ till en samtalstopik i samma episod och därmed styra samtalet, men när de inte tar den möjligheten är det istället handledaren som styr och initierar en topik. Detta är en ganska vanlig utveckling när det gäller frågor som på ett allmänt plan överlämnar möjligheten att styra och ta över samtalet till studenterna (jfr punkt I ovan).

Öppnande och överlämnande frågor möjliggör alltså delaktighet för studenterna och ibland, men inte alltid, tas den möjligheten tillvara. Ibland får dessa frågor ganska korta studentresponser som svar och effekt men vid flera tillfällen leder dock de något mer styrande öppnande och överlämnande frågorna också till längre och mer utvecklade studentresponser och studentinitiativ (jfr exempel 3). 
Utvecklande och fördjupande frägor

Handledarna ställer frågor som utvecklar och fördjupar studenternas delaktighet på olika sätt. Utvecklande och fördjupande frågor är i första hand neutrala och informationssökande, där handledaren vill ha information från studenten som handledaren inte har tillgång till. Vissa av frågorna fungerar både som information till handledaren och som fördjupning och utveckling av topiker för studenten. Frågor som "Vad finns det för närliggande begrepp?" $\left(\mathrm{H}_{2}, \mathrm{~S}_{2}\right)$, "Vad gav analysen?" (HI, S2), ”Hur har ni tänkt kring det?" $\left(\mathrm{H}_{4}, \mathrm{~S}_{\mathrm{I}}\right)$ och ”Ska du intervjua lärarna" $\left(\mathrm{H}_{2}, \mathrm{~S}_{2}\right)$ syftar till att studenten ska utveckla, förtydliga och fördjupa sina tankar. Många av dessa frågor är kvesitiva (Linell, 20II, s. 322), frågeordsfrågor som ofta inleds med vad, när, hur och varför. Kvesitiva frågeordsfrågor kan vara både utvecklande och fördjupande eller problematiserande och utmanande beroende på kontext, och ibland är det frågan om gränsfall. I dessa kontexter verkar det inte vara något som handledaren uppfattar som bristfälligt och problematiskt, utan här verkar det handla om just att efterfråga information som handledaren inte har. I en annan kontext hade till exempel "Vad gav analysen?" kunnat vara utmanande och problematiserande. Frågorna ställs ofta som del av längre resonemang, i anslutning till både textåterkoppling och till studenternas beskrivning av arbetsprocess och planer.

De utvecklande och fördjupande frågorna efterfrågar och får ofta effekten just att studenterna som respons utvecklar, fördjupar och preciserar sina resonemang. I exempel 3 efterfrågar handledaren en beskrivning av studenternas arbetsprocess, och i det sammanhanget ställer handledaren frågor som får studenterna att fördjupa och utveckla sin beskrivning av denna arbetsprocess.

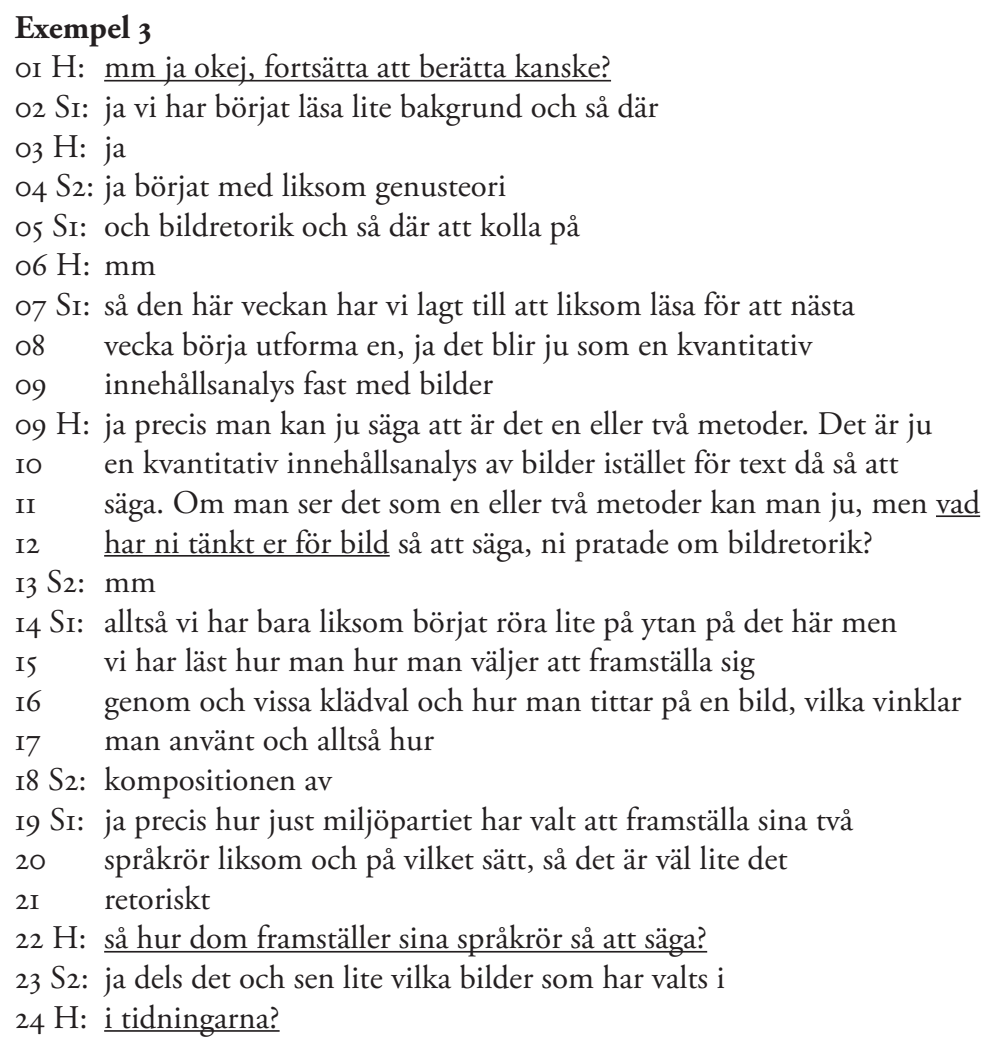




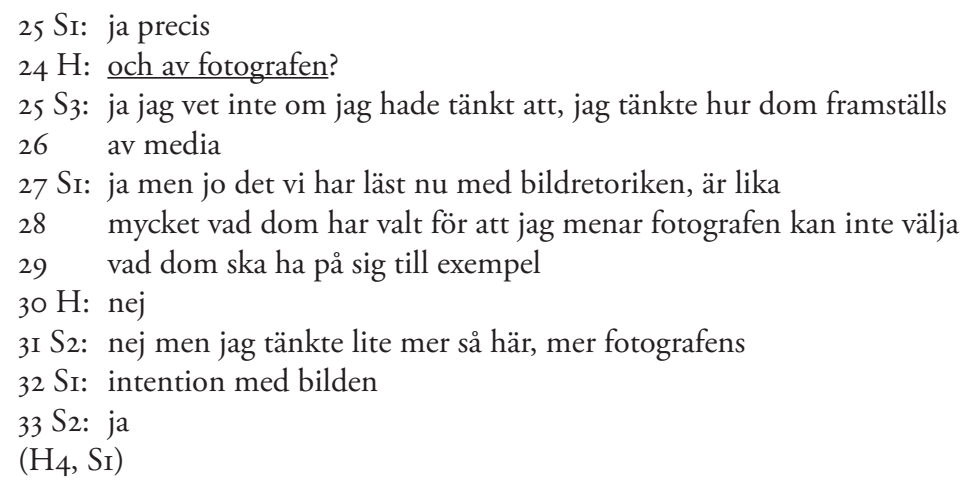

Handledaren inleder episoden med att ställa en öppnande och överlämnande fråga som möjliggör delaktighet i form av att studenterna ges möjlighet att styra diskussionen och beskriva sin arbetsprocess, "fortsätta att berätta kanske?" ( $\mathrm{rad}$ I). Studenterna beskriver då som respons hur de har tänkt, sådant som inte framgår i deras textutkast. Detta är ett exempel på hur öppnande och överlämnande frågor också kan leda till utvecklade studentinitiativ (jfr avsnitt 4.I).

Studenterna beskriver att de ska börja med att läsa och att de sedan ska börja utforma en "kvantitativ innehållsanalys fast med bilder" ( $\operatorname{rad} 7-8)$. Handledaren ställer då en fråga som fungerar utvecklande, om vad de har tänkt sig för bild(analys) (rad II). Detta leder till en relativt utförlig beskrivning av studenterna, där handledaren emellanåt ställer bekräftande frågor för att se att det som studenterna säger förstås rätt; "så hur dom framställer sina språkrör så att säga?" ( $\operatorname{rad} 20)$ och "i tidningarna?" ( $\operatorname{rad} 22)$ och "och av fotografen?" ( $\operatorname{rad} 24)$.

Handledarens funktion i denna samtalsepisod är att öppna för studenternas perspektiv, få studenterna att fördjupa sitt perspektiv, utveckla hur de menar och bekräfta att det hela har förståtts rätt. Studenterna har lämnat in ett utkast inför handledningen, men handledaren får genom frågorna studenterna att ta upp mer än vad som framgår i utkastet och får dem att både motivera och förklara hur de har tänkt angående metodval och undersökningsdesign. Studenterna konstrueras genom sin respons som kompetenta deltagare i denna episod och får möjlighet till delaktighet både genom att styra topiken och att presentera sin förståelse och sina perspektiv, vilket är avgörande ur ett självständighetsperspektiv.

\section{Utmanande och problematiserande frägor}

Utmanande och problematiserande frågor är den vanligaste frågefunktionen i handledningssamtalen. Dessa frågor möjliggör en djupare förståelse för någon aspekt i uppsatsen, men möjliggör också för studenten att se den särskilda aspekten av uppsatsen utifrån ett annat perspektiv. Delaktighet handlar här om att studenten ges möjlighet att motivera och göra val, antingen direkt $\mathrm{i}$ interaktionen eller senare vid bearbetningen av den egna texten. Utmanande och problematiserande frågor förekommer framförallt vid återkoppling på i förväg lästa textutkast men också vid studentens rapportering av och beskrivning av arbetsprocessen. Därutöver kan de både inleda topiker eller fungera som respons i längre resonemang.

Först och främst förekommer kvesitiva frågor (Linell, 20II, s. 322), frågeordsfrågor som här syftar till förtydliganden och problematiseringar. Dessa frågor inleds oftast med frågeorden vem, vad, hur och varför, men också med fraser som utgår från "menar ni ...?”. Exempel här är "Vem är man?" $\left(\mathrm{H}_{3}, \mathrm{~S}_{2}\right)$, "Vad är det man kan läsa utav det?" $\left(\mathrm{H}_{4}, \mathrm{~S}_{2}\right)$, "Hur ska du mäta motivation?" $\left(\mathrm{H}_{2}, \mathrm{~S}_{2}\right)$, "Varför intervjuar du lärare och inte elever?" $\left(\mathrm{H}_{2}, \mathrm{~S}_{2}\right)$ och "Vad menar du med 
ämnen?” (HI, S2). Dessa frågor syftar sannolikt inte till att handledaren ska få mer information i första hand utan dessa frågor implicerar istället att det som står i texten eller det som har sagts i samtalet är otillräckligt motiverat och/eller problematiskt. Responsen från studenterna när det gäller dessa frågor blir också ofta en sorts försvar eller ursäkt, vilket ibland verkar tillräckligt och ibland leder till ytterligare frågor. Här blir effekten alltså inte självklart en ökad delaktighet $i$ interaktionen, men möjligen istället en fördjupad delaktighet genom att studenten får möjlighet att fatta nya och andra beslut och förtydliga oklarheter i den egna texten. Den här typen av frågor kan relateras till den sokratiska metoden, där läraren eller handledaren konstruerar "thought-provoking questions that expose the student's misconceptions and contradictions" (Graesser \& Person, 1994, s. I06). Det är dock omöjligt att utifrån responserna i interaktionen veta hur dessa frågor hanteras av studenten.

De utmanande och problematiserande frågorna kommuniceras på olika sätt i interaktionen. Ibland kommer enbart en fråga och ibland följs frågan av ytterligare frågor, ett råd eller explicit kritik. När en utmanande eller problematiserande fråga ställs utan någon uppföljning får frågan som funktion att lyfta en problematisk aspekt eller utmana studenten, men att studenten själv får avgöra vad denne ska göra av den, om förtydliganden eller tillägg kan behöva göras. Det fungerar då som en sorts implicit kritik. Vanligare är dock att en problematiserande fråga följs av ett råd eller av explicit kritik. Denna särskilda struktur med fråga, svar och efterföljande råd uppmärksammas även i Vehiläinen (20I2).

I exempel 4 frågar handledaren vad ett särskilt analysperspektiv som studenterna testat gav, en analys av om journalister har skrivit ut frågorna eller ej i publicerade intervjuer.

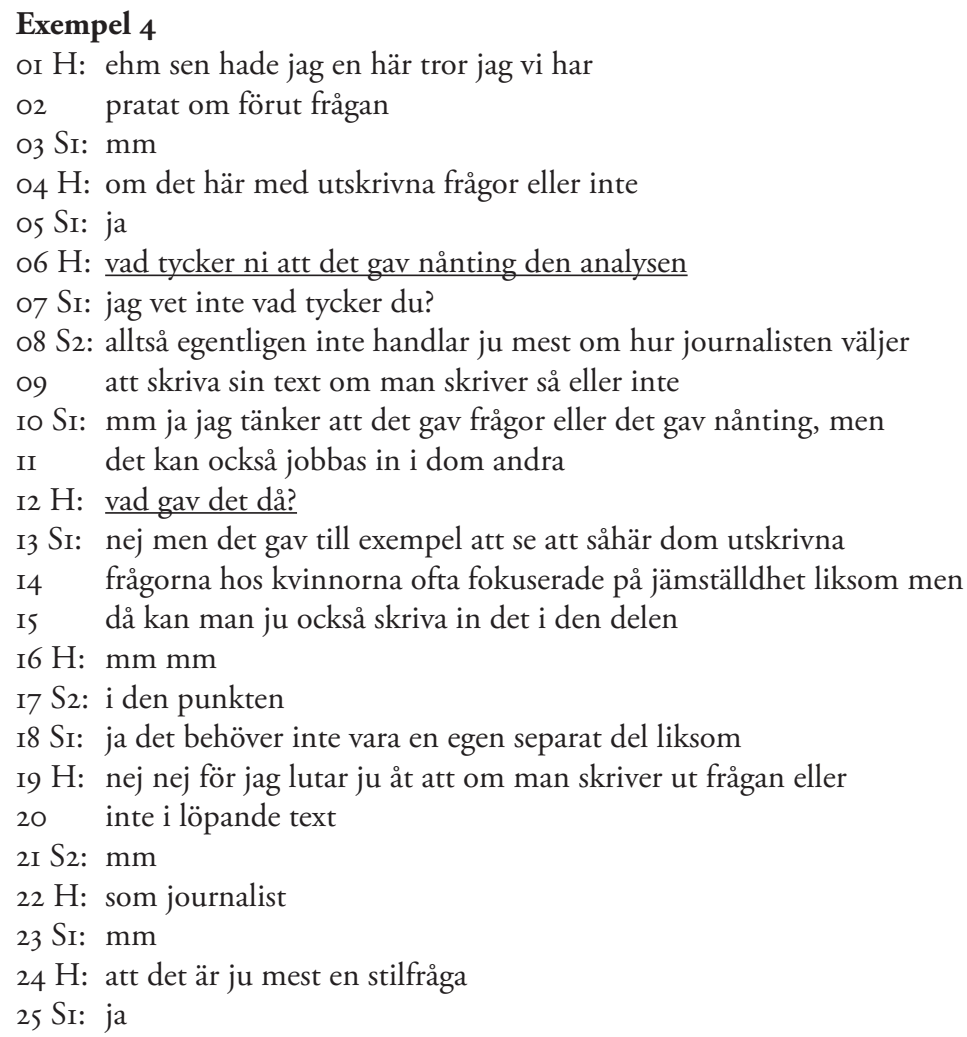


26 S2: jag tycker det är en lathetsfråga

$27 \mathrm{H}$ : om man gör det eller inte

28 S2: (skrattar)

29 Si: (skrattar) då vet vi hur dina intervjuer kommer se ut

$30 \mathrm{H}$ : ja men det kan det väl vara också

$\left(\mathrm{H}_{1}, \mathrm{~S}_{2}\right)$

Handledaren är den som initierar topiken och episoden, "det här med utskrivna frågor eller inte" ( $\mathrm{rad} 4)$. Direkt efter att topiken initierats ställs en utmanande och problematiserande fråga: "Vad tycker ni att det gav någonting den analysen?" ( $\operatorname{rad} 6)$. Att frågan inte tolkas som neutral och utvecklande här beror på att handledaren har läst studenternas analys av detta i det utkast som ligger till grund för handledningen, vilket tyder på att studenterna inte har lyckats synliggöra relevansen av analysen i sin skrivna text och att analysen ses som problematisk av handledaren.

Studenterna svarar på vad analysen gav, men orienterar sig också mot det kritiska och problematiserande anslaget genom att lägga till "men det kan också jobbas in i dom andra" (rad I2) samt "men då kan man också skriva in det i den delen" ( $\operatorname{rad~I6-I7).~Båda~dessa~kommentarer~}$ tyder på att studenterna uppfattar att handledaren inte anser att detta analysperspektiv är ett relevant perspektiv i sig själv. Att handledaren sedan upprepar den utmanande och problematiserande frågan ( $\mathrm{rad}$ I2) tyder på att studenternas svar inte var tillräckliga och detta förstärker det problematiserande anslaget ytterligare. Episoden avslutas med att handledaren formulerar sin åsikt explicit, att journalisternas val att ha med eller inte ha med intervjufrågor mest handlar om en stilfråga ( $\operatorname{rad} 2 \mathrm{I}-22,26)$ och därför inte har någon större relevans $\mathrm{i}$ en analys. Episoden avslutas med skratt, vilket tyder på att studenterna accepterat det som handledaren har sagt, även om det inte explicit framgår vad studenterna väljer att göra med analysaspekten ifråga. Denna episod kan tolkas som att handledaren uppmuntrar och ger studenterna en möjlighet att motivera och förklara hur de tänker och hur perspektivet ifråga har relevans. När de inte klarar av detta i tillräcklig utsträckning presenterar handledaren sin åsikt som visar att denne inte anser det vara relevant. Här hade den fördjupade delaktigheten dels kunnat visa sig i interaktionen om studenterna verkligen hade trott på och hade kunnat motivera sina val, dels kunnat visa sig i nya synsätt som skulle kunna användas i det fortsatta arbetet.

Att ställa negativt formulerade frågor (jfr negative interrogatives, Heritage, 2002, s. I428; Linell, 20II, s. 320) är en mer extrem form av utmanande och problematiserande frågor. Handledarna uttrycker kritiska och problematiserande påståenden och åsikter genom att formulera dessa som frågor: "Men du har inte börjat skriva så mycket än?” ( $\left.\mathrm{H}_{2}, \mathrm{~S}_{2}\right)$, ”Du har inte heller någon riktig slutkläm?" $\left(\mathrm{H}_{3}, \mathrm{~S}_{2}\right)$ och "Ni har inte gjort något provurval?" $\left(\mathrm{H}_{4}, \mathrm{~S}_{\mathrm{I}}\right)$. Dessa negativt formulerade frågor indikerar att det finns en norm och en förväntan som inte har uppfyllts, att de skulle ha skrivit mycket mer, att de skulle ha formulerat en slutkläm och att de borde ha gjort ett provurval. Sådana frågor möjliggör fördjupad delaktighet på i princip samma sätt som andra utmanande och problematiserande frågor, men i praktiken försvarar sig studenterna mer än motiverar och utvecklar det egna lärandet utifrån vad som framgår i interaktionen.

I andra exempel ställer handledaren flera frågor om en och samma topik, där frågorna blir mer och mer utmanande och problematiserande. I exempel 6 ställer handledaren flera frågor och följdfrågor om motivationsbegreppet. 


\section{Exempel 6}

or $\mathrm{H}$ : eh (...) men hur tänker du kring det här motivationsbegreppet?

O2 S: (suckar) ja nu snurrar det hela tiden så fort jag liksom,

O3 (suckar), ja hur tänker man, (suckar)

$04 \mathrm{H}$ : alltså om jag ställer frågan så här utifrån dina frågeställningar,

05 eh vad är motivation, hur ska du

06 S: det är en inre drivkraft som man kan få inifrån eller, då med hjälp

$07 \quad$ av, yttre saker som gör att man drivs av att uppnå nånting

oq H: hur ska du mäta motivation?

Io S: ja, deras upplevelse, [namn] skriver att det måste ju liksom, barnens

II upplevelse liksom hur dom, vad dom känner sig motiverade av

I2 $\mathrm{H}: \mathrm{mm}$

I3 S: så att säga för det går ju aldrig att veta om dom blir mer eller

I4 mindre motiverade, om man inte gör samma sak på två olika sätt,

I5 tänker jag, men det är ju det ja det är enkätform, som eller alltså

I6 dom kommer svara på enkäter, om motivation

I7 H: och om du då, kommer åt deras upplevelser, hur vet du om dom sen har

I8 blivit, om det har fått nån liksom effekt?

I9 $S:$ m nej precis, det är svårt

$20 \mathrm{H}$ : jag tänker liksom, hur liksom långt kommer dina resultat att nå?

2I $\mathrm{S}: \mathrm{mm}$, ja det är frågan

$23 \mathrm{H}$ : jag ställer frågor för att förstå vad som kommer

24 att bli din, mer så här avgränsning definition syftesformulering

$25 \mathrm{~S}$ : ja vill mer alltså, frågan är ställd lite att vad dom blir motiverade

26 av i skolan så att säga, det är både digitalt, lärarens undervisning

27 eller grupparbete eller praktiskt arbete eller liksom, så att se

28 vilken, om det nu är den digitala verkligen är motiverande, det

29 kanske inte alls är det, det får vi ju se liksom, men dom flesta

30 studier som man läser så är ju det digitala är ju

3I motivation, en inre motivationskraft liksom för att få det att

32 fungera, eller nå sin mål, så tänkte jag intervjua lärarna och se om

33 dom får samma, om dom upplever samma sak som dom här enkäterna visar,

34 att jämföra dom då liksom

$35 \mathrm{H}: \mathrm{m}$ men när dom, upplever att dom har blivit motiverade, vad är det du

36 tänker att dom har blivit motiverade att göra då? är det att spela

37 mer minecraft eller är det att tillgodogöra sig ämnesstoffet? eller

$38 \mathrm{~S}:$ ja, ja lite mer så att det liksom

$39 \mathrm{H}:$ eller den tredje grejen skulle kunna va alltså nyfiken på att söka

40 S: vidare ja, ja

4I H: vidare eller information själv alltså en motivation att söka vidare,

42 det här inre som du var inne på

$43 \mathrm{~S}: \mathrm{m}$ ja

$44 \mathrm{H}$ : alltså att dom ställer frågor till samhällskunskapsämnet, efter att

45 ha spelat minecraft det är ju

$46 \mathrm{~S}$ : ja och det bygger väl på att som jag förstår lärarna så gör man ju

47 liksom uppgifter kring SO, det är ju inte att spela minecraft bara

48 för att spela minecraft, dom får en specifik uppgift i minecraft som

49 dom ska utföra liksom

50 H: m

5I S: vad jag förstår, jag har inte hunnit träffa dom här lärarna jag ska 


\section{Jenny Magnusson}

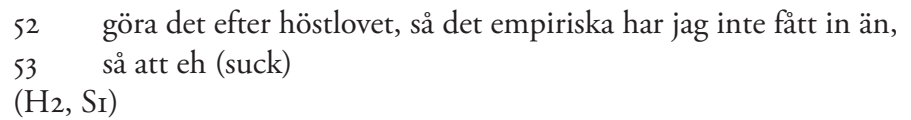

Användandet av återkommande följdfrågor eller flerledade frågeturer tjänar ofta till att lösa ett kommunikativt dilemma, vilket Linell menar kan uppstå i samtal som inrymmer flera syften "av vilka några är åtminstone delvis inbördes motstridande, samtidigt som mötet går ut på att finna någon slags lösning." (Linell, 20II, s. 572). I just det här fallet är det rimligt att tänka sig att handledarens behov av att upprätthålla en god relation till studenten och samtidigt diskutera och få studenten att förstå ett större problem skapar ett sådant dilemma, där handledaren ställer sex frågor om ett och samma problemområde. Handledaren inleder med en öppen fråga, men ställer sedan problematiserande och utmanande följdfrågor som leder studenten genom olika lager av problemområdet.

Handledaren inleder med en öppen eller möjligen utvecklande fråga där hen undrar "hur tänker du kring det här motivationsbegreppet" ( $\mathrm{rad} \mathrm{I})$. Här finns inget utmanande och ingen problematisering, utan handledaren öppnar här för att studenten själv ska beskriva olika perspektiv på begreppet motivation. När studenten har svårt att svara på den öppna eller utvecklande frågan ställer handledaren en grundläggande fråga om "Vad är motivation" ( $\operatorname{rad} 5)$. Studenten svarar att det är en inre drivkraft och då ställer handledaren en ytterligare mer problematiserande följdfråga: "Hur ska du mäta motivation?" (rad 9). Studenten tar då upp att det handlar om inre upplevelser, och utifrån detta frågar då handledaren ytterligare en problematiserande fråga om hur det går att se om upplevelserna har fått någon effekt ( $\mathrm{rad}$ I7-I8). När studenten håller med om att det är problematiskt och svårt ställer handledaren samma fråga på ett annat sätt och drar genom denna fråga ut konsekvenserna av problemet: "Hur långt kommer dina resultat att nå?” (rad 20). När studenten inte svarar på den frågan heller, så förklarar handledaren sitt syfte med att ställa frågorna: "jag ställer frågor för att förstå vad som kommer att bli din, mer så här avgränsning definition syftesformulering" ( $\operatorname{rad} 23-24)$. Detta kan tolkas som ett försök att tona ner det riskabla i att ställa utmanande och problematiserande frågor, och kanske också tona ner det faktum att studenten har svårt att svara.

Efter denna förklaring ger studenten ett svar med olika infallsvinklar i, men handledaren verkar inte anse att detta räcker då den utmanande och problematiserande frågan ställs ännu en gång, "men när dom upplever att dom har blivit motiverade, vad är det du tänker att dom har blivit motiverade att göra då?” ( $\operatorname{rad} 35-36)$. Handledaren ger här också förslag eller alternativ som de sedan resonerar om, även om studenten fortfarande inte formulerar ett svar på frågan. Frågorna möjliggör respons i form av beskrivningar av val och motiveringar, men leder i detta exempel endast till respons i form av korta responser på de olika konkreta förslag handledaren ger.

I dessa olika exempel framgår att utmanande och problematiserande frågor kan ställas på olika sätt och möjliggöra mer eller mindre delaktighet. Ibland överlämnas åt studenten att avgöra hur det som frågan rör ska hanteras. Frågan kan också följas av explicit kritik eller konkreta förslag och rekommendationer. Frågorna accepteras ofta utifrån vad som framgår i samtalet, men verkar ofta uppfattas som kritiska. Ofta rör frågorna något som handledaren uttrycker som otillräckligt motiverat eller problematiskt och genom frågorna har studenterna möjlighet att se på sina val och sina perspektiv på nya sätt, men det är oklart utifrån interaktionen i vilken utsträckning detta sker, genom att studenternas responser ofta är korta och inte så informativa. 


\section{DISKUSSION}

Denna undersöknings syfte är att undersöka frågor som möjliggör självständighet hos studenten; vilka sådana frågor som används och hur variationen dem emellan ser ut utifrån olika perspektiv. Självständighet ses här som delaktighet hos studenten. Studenter kan vara mer eller mindre delaktiga i handledningssamtalen på olika sätt, men här ligger fokus på handledarens arbete för att skapa studentdelaktighet genom ställandet av frågor.

I ett institutionellt samtal är det ofta experten som ställer frågor och som därmed styr interaktionen (jfr Linell, 2OII, s. 3I8), och detta gäller såväl studenthandledning som läkar- och patientsamtal. Det finns dock sätt att öppna för en mer jämställd och symmetrisk interaktion i handledning, mer i linje med vad Dysthe (2002) kallar för partnerskapsmodellen, där studenten är aktiv och aktör i ett jämställt samspel. Detta ligger också i linje med en generell samhällelig förändring mot ett ideal där hierarkiska arbetsplatser med auktoritära strukturer blir alltmer jämställda och öppnar för olika typer av delaktighet (jfr Freed \& Ehrlich, 20Io). I Sarangis analys av sjukrådgivning (20IO) identifieras till exempel en "ethos of nondirectiveness" som ska uppmuntra "reflection-based decision-making". Detta ligger nära handledningens utgångspunkt och mål, som handlar just om samspel och om reflektioner runt val och motiveringar. I ett handledningssamtal byggs en sådan jämställd och symmetrisk delaktighet upp bland annat genom vilka frågor som ställs och hur dessa ställs.

På en generell nivå är samtliga samtal som analyseras i denna undersökning handledarstyrda i linje med hur institutionella samtal oftast ser ut, där handledaren är den som i första hand styr interaktionen och som styr vilka samtalstopiker som ska tas upp och diskuteras. Samtliga handledare använder dock ett stort antal frågor som på olika sätt möjliggör delaktighet. Det är tre typer av frågefunktioner som har identifierats som särskilt möjliggör studentens delaktighet i de undersökta samtalen: öppnande och överlämnande, utvecklande och fördjupande och problematiserande och utmanande frågor. De olika frågefunktionerna skapar möjlighet för olika typer av delaktighet, där det handlar om att öppna för, utveckla eller fördjupa delaktigheten på olika sätt.

De utmanande och problematiserande frågorna, som skapar möjlighet till självständighet i form av en fördjupad delaktighet, är vanligast hos handledarna. Den handledarroll som oftast realiseras genom dessa frågor, där kritik ofta är en implicit eller explicit del av frågeepisoden, är en expertroll som delvis ligger nära det som Dysthe benämner undervisningsmodellen (2002). Här blir handledarens roll att identifiera och påtala svagheter och oklarheter i första hand. Genom frågeformen ges dock inte självklart några svar och förslag på hur studenten kan hantera detta utan studenterna ges möjlighet att själva förstå, göra val och hitta lösningar. Huruvida studenterna verkligen får en egen förståelse eller identifierar egna lösningar är mer oklart om man ser till interaktionen. Oftast verkar studenterna acceptera den underliggande kritiken och de ger ofta uttryck för att förstå vad som avses, men utvecklade lösningsförslag och strategier framkommer mer sällan i interaktionen. Här hade senare inlämnade textversioner kunnat säga mer om hur studenterna utifrån handledarnas frågor hade hittat egna strategier och lösningar.

Pedagogiskt framgår att frågorna kan bidra till att hantera dilemman för handledaren, till exempel genom att handledaren kan använda problematiserande och utmanande frågor för att ge implicit kritik till studenten. Att ge kritik explicit kan vara ansiktshotande (jfr Brown \& Levinson, 1987), och genom frågeformen kan effekten mildras. Att därutöver använda sig av flera problematiserande och utmanande följdfrågor verkar också pedagogiskt vara en vanlig strategi för att leda studenterna vidare i sitt tänkande när enstaka frågor inte verkar räcka till. 
Det är alltså ett komplext uppdrag som handledarna har när det gäller att ge kritik och att få studenten att förstå denna kritik på ett icke-ansiktshotande sätt, och där kan frågorna fylla en viktig funktion.

Frågor som öppnar för och överlämnar initiativ och ansvar till studenter, för såväl val av ämne som styrande av samtalet, används också av alla handledare men mer sällan i detta material. Dessa frågor möjliggör dock en mer symmetrisk handledarroll som mer ligger i linje med Dysthes partnerskapsmodell (2002). Detta gäller också de utvecklande och fördjupande frågorna, där det är en annan form av fördjupning som avses jämfört med de utmanande och problematiserande frågorna. Studenternas fördjupande delaktighet och därmed fördjupande självständighet möjliggörs genom följdfrågor som leder studenterna vidare i tankegångar och resonemang.

Resultaten i denna undersökning visar dock att variationen är stor såväl mellan olika handledare som mellan olika delar av handledningssamtalen. Alla handledare använder alla typer av frågor men de använder frågorna på olika sätt i olika samtal och i olika delar av samtalen. Detta tyder på att det är svårt att hävda att handledarna har en särskild handledarmodell eller handledarroll liknande ovannämnda partnerskapsmodell eller undervisningsmodell (Dysthe, 2002) utifrån dessa frågefunktioner. Här kan man istället beskriva det som att handledarna använder olika strategier i interaktionen beroende på studentens behov och respons, eller beroende på var i processen studenten befinner sig. Det verkar här alltså mer handla om situerade handledarstrategier i särskilda episoder snarare än generella handledarmodeller. Utmanande frågor kan till exempel användas i inledande samtal för att möjliggöra och stötta val när det gäller ämne, metod och material, eller i sista samtalet för att synliggöra otydligheter och motsägelsefullheter som behöver åtgärdas i ett nästan färdigt uppsatsmanus.

I undersökningen fokuseras handledarens möjliggörande av och öppnande för självständighet genom ställandet av frågor, men detta är dock inte detsamma som att studentens faktiska fördjupade delaktighet påverkas. Att undersöka vilken effekt frågorna får handlar till stor del om att se hur studenterna svarar på och utnyttjar möjligheten till fördjupad delaktighet som erbjuds. När studenterna genom öppna och överlämnade frågor uppmanas att berätta vad de har gjort inom ett särskilt område leder detta ofta till initiativ och delaktighet i form av beskrivningar och resonemang. Studenterna tar också oftast tillvara möjligheten till fördjupad delaktighet när det gäller utvecklande och fördjupande frågor som ställs.

I de frågeepisoder som undersökts i denna studie är det dock inte självklart att studenterna tar det utrymme som erbjuds och det är inte självklart att det blir annat än korta inlägg och kommentarer av de initiativ som tas (jfr exempel I, 2). När handledarna ställer helt öppna frågor angående vad studenterna vill diskutera eller prata om avböjer studenterna ofta, och anger skäl som att de ännu inte har hunnit komma så långt eller att de inte har tänkt på något särskilt. Här orienterar sig studenterna mot en handledarroll där handledaren är den som har ansvar för och förväntas styra samtalet och vad som är relevant att diskutera. Detta har sannolikt att göra med de institutionella och asymmetriska rollerna, som kan vara svåra att bortse från. När handledarens öppna frågor styr den övergripande topiken, men öppnar för studentens perspektiv på denna topik, blir det dock ofta en större och mer utvecklad delaktighet. Det verkar alltså vara lättare för studenten att vara delaktig i interaktionen om det finns ramar för detta i form av föreslagna övergripande topiker.

När det gäller problematiserande och utmanande frågor ser delaktigheten annorlunda ut. Där handlar studenternas respons oftast om att förklara och motivera, men också om att acceptera att ett valt perspektiv eller begrepp är problematiskt och inte fungerar. Någon ökad delaktighet 
är alltså inte alltid synlig i dessa fall, men möjligen en fördjupad delaktighet. Vad som händer med det nya perspektivet efter handledningssamtalets slut är inte möjligt att veta utifrån interaktionen. Det behöver kanske dock inte alltid vara avgörande att studenterna verkligen svarar på och resonerar runt handledarens frågor direkt $i$ alla lägen, utan snarare att de visar att de förstår vad som avses, vilket längre fram kan leda till respons och delaktighet i olika former (jfr Koshik, 2010, s. I82).

Man kan sammanfattningsvis se att det finns många exempel på att frågorna leder till politisk delaktighet (jfr Koster et al., 2009) där studenter motiverar och väljer, men samtidigt att denna delaktighet inte alltid uppnås genom de olika frågetyperna. Huruvida dessa frågestrategier och den delaktighet som dessa leder till är effektiva för textbearbetning och fördjupad förståalse jämfört med vad rena instruktioner och konkreta uppmaningar skulle vara är svårt att säga utan att en sådan jämförande analys har genomförts (jfr Koshik, 20IO, s. I84).

Att frågeformatet generellt leder till studentdelaktighet, även om det gäller mer för vissa typer av frågor än för andra, har dock ett värde i sig. Upplevelsen av handledningen som lärande torde också påverkas av att studentens uppfattningar, beskrivningar och motiveringar ges relevans och att studenterna uppmanas och ges möjlighet att själva formulera tankar och utgångspunkter runt sitt uppsatsskrivande. Studenten blir alltså genom frågorna en kompetent deltagare $\mathrm{i}$ handledningssamtalet, inte enbart genom det textutkast som eventuellt har lämnats in utan också genom den förståelse och den kunskap som studenten muntligt ger uttryck för (jfr Vehviläinen, 20I2). Genom detta skapas förutsättningar för ett mer reellt, ömsesidigt och symmetriskt samspel i handledningen, vilket gynnar lärande och kvalitet i högre utbildning. Flera av dessa frågor är alltså användbara verktyg för en handledare som vill få studenten att själv reflektera runt luckor, svagheter och möjligheter i sitt material, utan att handledaren ska behöva beskriva precis vad studenten ska göra.

De problematiserande och utmanande frågorna leder ibland, men mer sällan, till att tankar och resonemang introduceras och utvecklas i interaktionen. Studenterna triggas till att motivera och förklara och ibland försvara sina val och när detta görs i interaktionen så blir även dessa frågor ett viktigt redskap. Det är dock lika vanligt med korta och informationsfattiga responser på dessa frågor i interaktionen, och där är det svårare att se hur frågorna får studenterna att tänka nytt, fatta nya beslut etc. Dessa frågor positionerar handledaren mer tydligt som expert och det framgår att handledaren i kraft av sin institutionella roll styr samtalen.

Frågorna fungerar alltså både som verktyg för kontroll och expertis och för delaktighet och samspel, och som handledare är det därför viktigt med en medvetenhet om vad man är ute efter när frågor ställs till en student.

\section{FÖRFATTARPRESENTATION}

Jenny Magnusson (jenny.magnusson@sh.se) är docent i svenska och arbetar på Södertörns högskola. Hon undervisar i uppsatskurser på lärarprogrammet och på högskolepedagogiska kurser om handledning och akademiskt skrivande. Forskningsintressen rör också skrivande, akademiskt skrivande och handledning. Hon har en bakgrund som gymnasielärare.

\section{REFERENSER}

Ainsworth-Vaughn, N. (1998). Claiming Power in Doctor-patient Talk. Oxford: Oxford University Press on Demand.

Banbrook, L. \& Skehan, P. (1990). Classrooms and Display Questions. I: Brumfit, C. \& Mitchell, R. (Red.), Research in the Language Classroom, s. 141-152. ELT Documents 133. 


\section{Jenny Magnusson}

Bergmark, U. \& Westman, S. (2016). Ökat studentengagemang genom delaktighet och inflytande i högre utbildning: studenters och lärares samskapande av undervisningens innehåll och genomförande. Högre utbildning 6(1), 51-64.

Brown, P. \& Levinson, S. C. (1987). Politeness: Some Universals in Language Usage. Cambridge University Press: Cambridge.

Bubel, C. (2005). The Linguistic Construction of Character Relations in TV Drama: Doing Friendship in Sex and the City. Doktorsavhandling. Saarbrücken: Saarland University.

Dysthe, O. (2002). Professors as Mediators of Academic Text Cultures: an Interview Study with Advisors and Masters Degree Students in Three Disciplines in a Norwegian University. Written Communication $19(4), 493-544$.

Ekholm, D. (2012). Handledning av examensarbeten som lärande i the zone of proximal development. Högre utbildning 2(2), 67-78.

Forsberg, E. \& Lundgren, U. P. (2006). Examensarbeten inom den nya lärarutbildningen. Stockholm: Högskoleverket.

Frank, J. (1990). You Call that a Rhetorical Question? Forms and Functions of Rhetorical Questions in Conversation. Journal of Pragmatics, 14(5), 723-738.

Freed, A. (1994). The Form and Function of Questions in Informal Dyadic Conversation. Journal of Pragmatics 21(6), 621-644. doi: https://doi.org/10.1016/0378-2166(94)90101-5

Freed, A. \& Ehrlich, S. (2010). Why Do You Ask? The Function of Questions in Institutional Discourse. New York: Oxford University Press.

Graesser, A. C. \& Person, N. (1994). Question Asking During Tutoring. American Educational Research Journal 31(1), 104-137.

Gustavsson, S. \& Eriksson, A. (2015). Blivande lärares frågor vid handledning - Gör jag en kvalitativ studie med kvantitativa inslag? Pedagogisk forskning i Sverige 20(1-2), 79-99.

Heath, S. B. (1982). Questioning at Home and at School: A Comparative Study. Doing the Ethnography of Schooling: Educational Anthropology in Action, 102-131.

Heinemann, T. (2008). Questions of Accountability: Yes-No Interrogatives that are Unanswerable. Discourse Studies 10(1), 55-71.

Heritage, J. (2002). The Limits of Questioning: Negative Interrogatives and Hostile Question Content. Journal of Pragmatics 34(10-11), 1427-1446.

Hofvendahl, J. (2000). Flerledade frågor $i$ institutionella samtal. Magisteruppsats från tema K. Linköping: Linköpings universitet.

Holmes, J. (1992). Women's Talk in Public Contexts. Discourse and Society. 3(2), 131-150.

Holmes, J. \& Chiles, T. (2010). Is that Right? Questions and Questioning as Control Devices in the Workplace. I: Freed, A. \& Ehrlich, S. (Red.), Why Do You Ask?: The Function of Questions in Institutional Discourse, s. 187-210. New York: Oxford University Press.

Koshik, I. (2010). Questions that Convey Information in Teacher-Student Conferences. I: Freed, A. \& Ehrlich, S. (Red.), Why Do You Ask? The Function of Questions in Institutional Discourse, s. 159-186. New York: Oxford University Press.

Koster, M., Han Nakken, S. J. P. \& Van Houten, E. (2009). Being part of the peer group: A literature study focusing on the social dimension of inclusion in education. Review of International Journal of Inclusive Education, 13(2), 117-40.

Lendahls Rosendahl, B. (1998). Examensarbetets innebörder. En studie av blivande lärares utsagor. Doktorsavhandling. Goteborg: Goteborgs universitet.

Linell, P. (2011). Samtalskulturer. Kommunikativa verksambetstyper i sambället. Linköping: Linköpings universitet, Institutionen för kultur och kommunikation.

Linell, P., Hofvendahl, J. \& Lindholm, C. (2003). Multi-unit Questions in Institutional Interactions: Sequential Organizations and Communicative Functions. Text - An Interdisciplinary Journal for the Study of Discourse, 23(4), 539-572. 
Magnusson, J. \& Sveen, H. (2013). Topikalitet i handledning. I: Rosén, C., Simfors, P. \& Sundberg, A. (Red.), Språk i undervisning: ASLA:s vairsymposium Linköping, 11-12 maj, 2012, s. 173-182. ASLA, Linköping: Linköpings universitet.

Magnusson, J. \& Sveen, H. (2014). Handledningens effektivitet: En studie av remediering i självständiga arbeten. Svenskans beskrivning 33, Helsingfors, 15-17 maj, 2013. Helsingfors: Helsingfors universitet.

Magnusson, J. (2015). Självständighetens praktik - Uppfattning och användning av begreppet självständighet i relation till det självständiga arbetet. I: Kahlin, L., Landqvist, M. \& Tykesson, I. (Red.), Språk och identitet: ASLA:s symposium, Huddinge, 8-9 maj, 2014, s. 91-105. ASLA, Huddinge: Södertörns högskola.

Magnusson, J. (2016). Text i samtal: Hur texter används som resurser i handledningssamtal. I: Gustafsson A. W., Holm, L., Lundin, K., Rahm, H. \& Tronnier, M. (Red.), Svenskans beskrivning 34: Förhandlingar vid trettiofjärde sammankomsten för svenskans beskrivning, Lund den 22-24 oktober 2014, s. 343-355. Lund: Lunds universitet, Lundastudier i nordisk språkvetenskap.

Magnusson, J. (2020a). "Jättebra, men" - Handledares beröm i handledningssamtal. Språk och interaktion, 5(3), 45-68.

Magnusson, J. (2020b). Oenighet i handledningssamtal: att säga emot sin handledare. Språk \& stil, NF 30, $175-204$

Magnusson, J. \& Zackariasson. M. (2018). Student Independence in Undergraduate Projects: Different Understandings in Different Academic Contexts. Journal of Further and Higher Education, 43(10), 1404-1419. doi: 10.1080/0309877X.2018.1490949.

Philips, S. U. (1984). The Social Organization of Questions and Answers in Courtroom Discourse: A Study of Changes of Plea in an Arizona Court. Text-Interdisciplinary Journal for the Study of Discourse 4(1-3), $225-248$.

Piirainen-Marsh, A. (2005). Managing Adversarial Questioning in Broadcast Interviews. Journal of Politeness Research 1(2), 193-217.

Rohde, H. (2006). Rhetorical Questions as Redundant Interrogatives, s. 134-168. UC San Diego, Department of Linguistics: San Diego Linguistics Papers 2.

Sarangi, S. (2010). Healthcare Interaction as an Expert Communicative System. New Advent Lang Interaction. 196, 167.

Schegloff, E., Jefferson, G. \& Sacks, H. (1974). A Simplest Systematics for the Organization of Turn-taking for Conversation. Language 50(4), 696-735.

Sinclair, J. \& Coulthard, M. (1992). Towards an Analysis of Discourse. I: Coulthard, M. (Red.), Advances in Spoken Discourse Analysis, s. 1-34. London \& New York: Routledge.

Skolverket. (2015). Delaktighet för lärande. Stockholm: Skolverket.

Studentkårer, Sveriges Förenade. (2013). Studentens lärande i centrum. SFS om pedagogik $i$ högskolan. Dnr: PU1-1/1213. Stockholm. Hämtad från: http://www. sfs. se/sites/default/files, 210325

Sveen, H. \& Magnusson, J. (2013). Handledningens vad, hur och varför - interaktionella mönster med fokus på röst. Högre utbildning 3(2), 87-102.

Säljö, R. (2000). Lärande i praktiken:ett sociokulturellt perspektiv. Stockholm: Prisma.

Vehviläinen, S. (2012). Question-prefaced Advice in Feedback Sequences of Finnish Academic Supervisions. I: Limberg, H. \& Locher, M. A. (Red.), Advice in Discourse, s. 31-52. Amsterdam/Philadelphia: John Benjamins Publishing.

Yieke, F. (2002). Language, Gender and Power: The Use of Questions as a Control Strategy in Workplaces in Kenya. Wiener Linguistische Gazette, 70-71.

Zackariasson, M. (2019). Encouraging Student Independence: Perspectives on Scaffolding in Higher Education Supervision, Journal of Applied Research in Higher Education, 12(3), 495-505. https://doi. org/10.1108/JARHE-01-2019-0012 